\title{
Correction to: Molecular mechanics and dynamic simulations of well-known Kabuki syndrome-associated KDM6A variants reveal putative mechanisms of dysfunction
}

\author{
Young-In Chi ${ }^{1,2,3}$, Timothy J. Stodola 1,2, Thiago M. De Assuncao 1,3, Elise N. Leverence' ${ }^{1}$, Swarnendu Tripathi ${ }^{1,2}$, \\ Nikita R. Dsouza 1,2, Angela J. Mathison 1,2,3, Donald G. Basel, ${ }^{1,4}$, Brian F. Volkman ${ }^{5}$, Brian C. Smith ${ }^{5}$, \\ Gwen Lomberk ${ }^{1,3,6}$, Michael T. Zimmermann ${ }^{1,2,7}$ and Raul Urrutia ${ }^{1,2,3,4^{*}}$
}

\section{Correction to: Orphanet J Rare Dis (2021) 16:66 https://doi.org/10.1186/s13023-021-01692- w}

After the publication of the original article [1], the authors became aware of the work by Petrizzelli et al., 2020 [2]. The two studies truly represent independent works, for which contents are different. Indeed, although both studies contain molecular dynamics data, each of them use different approaches as well as derived sets of analysis and interpretations which are different in depth of information. Therefore, both studies should be considered complementary to each other.

Furthermore, the authors became aware of a typo in Elise N. Leverence's family name. This has now been corrected in the original article, as well as the author list of this Correction. of Wisconsin, Milwaukee, WI, USA. ${ }^{3}$ Division of Research, Department of Surgery, Medical College of Wisconsin, Milwaukee, WI, USA. ${ }^{4}$ Division of Pediatric Genetics, Department of Pediatrics, Medical College of Wisconsin, Milwaukee, WI, USA. ${ }^{5}$ Department of Biochemistry, Medical College of Wisconsin, Milwaukee, WI, USA. ${ }^{6}$ Department of Pharmacology and Toxicology, Medical College of Wisconsin, Milwaukee, WI, USA. ${ }^{7}$ Clinical and Translational Sciences Institute, Medical College of Wisconsin, Milwaukee, WI, USA.

Published online: 01 June 2021

\section{References}

1. Chi, et al. Molecular mechanics and dynamic simulations of well-known Kabuki syndrome-associated KDM6A variants reveal putative mechanisms of dysfunction. Orphanet J Rare Dis. 2021;16:66. https://doi.org/10. 1186/s13023-021-01692-w.

\section{Author details}

${ }^{1}$ Genomic Sciences and Precision Medicine Center (GSPMC), Medical College of Wisconsin, Milwaukee, WI, USA. ${ }^{2}$ Bioinformatics Research and Development Laboratory, and Precision Medicine Simulation Unit, GSPMC, Medical College to the material. If material is not included in the article's Creative Commons licence and your intended use is not permitted by statutory regulation or exceeds the permitted use, you will need to obtain permission directly from the copyright holder. To view a copy of this licence, visit http://creativecommons.org/licenses/by/4.0/. The Creative Commons Public Domain Dedication waiver (http://creativeco $\mathrm{mmons}$.org/publicdomain/zero/1.0/) applies to the data made available in this article, unless otherwise stated in a credit line to the data. 
2. Petrizzelli, et al. Mechanisms of pathogenesis of missense mutations on the KDM6A-H3 interaction in type 2 Kabuki syndrome. Comput Struct Biotechnol J. 2020;18:2033-42.

\section{Publisher's Note}

Springer Nature remains neutral with regard to jurisdictional claims in published maps and institutional affiliations.

- fast, convenient online submission

- thorough peer review by experienced researchers in your field

- rapid publication on acceptance

- support for research data, including large and complex data types

- gold Open Access which fosters wider collaboration and increased citations

- maximum visibility for your research: over 100M website views per year

At BMC, research is always in progress.

Learn more biomedcentral.com/submissions 